İş ve İnsan Dergisi | The Journal of Human and Work

Y1l | Year: Ekim | October 2020

Cilt-Say1 | Volume-Issue: 7 (2)

ss I pp: 241-253

doi: 10.18394/iid.714735

e-ISSN 2148-967X

http://dergipark.gov.tr/iid/

Research Article

\title{
İş Güvencesizliği Algısında Sosyo-Demografik Değişkenlerin Etkisi: Otel İşletmelerinde Bir İnceleme
}

\author{
The Effect of Socio-Demographic Variables in the Perception of Job Insecurity: A Study \\ in Hotel Enterprises
}

Eray Polat ${ }^{\mathrm{a}}$

\section{MAKALE BILLGİSI}

Anahtar Kelimeler:

İş Güvencesizliği,

Sosyo-Demografik Değisken,

Otel Issletmeleri, Lojistik

Regresyon Analizi.

Tarihler :

Geliş 4 Nisan 2020

Düzeltme geliş 22 Mayıs

2020

Kabul 24 Haziran 2020

\section{ÖZ}

Günümüzde toplumsal, örgütsel, teknolojik ve politik alanda ortaya çıkan ve çalışma hayatını etkileyen değişiklikler, bazı açılardan çalışanları olumsuz etkileyebilmektedir. Bu olumsuzluklardan biri olan ve bu çalışmada üzerinde durulacak olan konu iş güvencesizliğidir. Bu kapsamda araștırmada iki soruya cevap aranmıştır. Bu sorulardan ilki, otel işletmeleri çalışanlarının iş güvencesizliği algısının hangi düzeyde olduğu ile ilgili iken; ikincisi sosyodemografik değișkenlerin iș güvencesizliği alglsl üzerinde hangi yönde ve ne derece etkisi olduğu ile ilgilidir. Nicel araştırma yönteminin kullanıldı̆̆ a araştırmada, Antalya ilinde bulunan otel işletmeleri çalışanları ile yüz yüze görüşülmüş ve anket tekniği ile veri toplanmıştır. Illk araştırma sorusunun cevabını verebilmek için ölçek ortalaması hesaplanmış; ikinci sorunun cevabı ise ikili lojistik regresyon analizi ile tespit edilmeye çalışılmıştır. Elde edilen sonuçlar otel işletmeleri çalışanlarının anket yapılan dönem itibariyle düşük seviyede iş güvencesizliği algısı taşıdıklarını göstermektedir. Ayrıca cinsiyet ve gelir düzeyinin iş güvencesizliği algısını etkilediği tespit edilmiştir. Buna göre erkek ve alt gelir grubunda yer alan çalışanların daha fazla iş güvencesizliği algısı taşıdıkları ifade edilebilir. Çalışmada, ulaşılan sonuçlara göre uygulayıcılara çeşitli öneriler sunulmuştur.

\section{A B S T R A C T}

Women entrepreneurship makes significant contributions to the level of economic development in the world. However, different from developed economies women entrepreneurs meet more difficult and challenging situations in developing economies. Further to that women participation in workforce and entrepreneurship process is much lesser in the countries where the gender gap is high. According to some study findings, independently of disadvantageous conditions and the level of economic development, how women entrepreneurs become successful is the issue of concern. Thus, the aim of the study is to explore the experiences, success factors, and personal and social results of women entrepreneurship process. The semi-structured interview method was employed in the study. A total of 30 entrepreneur women participated in the research. The results showed that apart from personal characteristics the environmental support is also significant in the women entrepreneurship process. It was also understood that the self-perceptions change positively with the effects of decreasing inequality attitudes towards women.

\footnotetext{
a Corresponding author, Dr. Öğr. Üyesi, Gümüşhane Üniversitesi Turizm Fakültesi Gastronomi ve Mutfak Sanatlart Bölümü, Gümüşhane, Türkiye. E-mail: eraypolat38@gmail.com, ORCID: 0000-0003-1470-4298
} 


\section{GíRiş}

Sanayi devrimi ile başlayıp Fordist dönemin sonlarına kadar etkisi devam eden süreçte emek ile sermaye arasındaki güven ya da bağlılık gibi duygular oldukça kuvvetliydi (Man, 2014: 59). Bu dönemlerde emekli olacak bir çalışan, ortalama dört işyerinde çalışır ve genelde emekli olacağı işyerindeki çalışma süresi uzun süreli olduğundan o işyeri ile adeta bütünleşirdi. Ancak günümüz işgücü piyasası koşulları, bunu çok da mümkün kılmamaktadır. Çünkü daha otuzlu yaşlarını biraz geçmiş ve henüz genç sayılabilecek çalışanlar neredeyse dokuz kez işyeri değiştirmektedir (Standing, 2017: 68). Bunun sebepleri arasında üretim teknolojilerinde, ekonomilerde, kamusal ve politik alanda yaşanan büyük değişim ve dönüşümler bulunmaktadır.

İşletmelerin, yaşanan bu değişim ve dönüşümlerden etkilenmesi kaçınılmazdır. $\mathrm{Bu}$ nedenle işletmeler bunlara uyum sağlayabilmek için üretim teknolojilerinde, iş süreçlerinde ya da çalışanları ile ilgili politikalarında çeşitli yenilikler yapmakta ve uygulamalar hayata geçirmektedir. Aynı zamanda bunların bir seçenek olarak değil, bir yükümlülük olarak yapıldığ 1 da söylenebilmektedir. Örneğin bunlardan biri, işletmenin esnekliğini artırabilmek ve değişen talebe göre çalışan sayısını artırıp azaltabilmesine imkân tanıyabilmek adına esnek çalışma sistemlerine geçmesi olabilir. $\mathrm{Bu}$ değişiklikler ile elbette ki, işletmenin en başta hayatına devam edebilmesi ve böylelikle çalışanların da bundan fayda sağlaması amaçlanmaktadır. Ancak çalışan tarafindan bakılınca bunlar dezavantajlı sonuçları da beraberinde getirebilmektedir. Bunlar arasında, çalışmanın konusunu oluşturması nedeniyle üzerinde durulacak olan konu iş güvencesizliğidir.

İş güvencesizliği algısının kaynağı, çalışanlar dişında gelişen olaylar olduğu gibi bir de bireysel bir yönü bulunmaktadır. Bu nedenle aynı işletmede, aynı kademede ve aynı haklara sahip olarak çalışan bireyler farklı düzeylerde iş güvencesizliği algısı taşıyabilmektedirler. $\mathrm{Bu}$ durum, iş güvencesizliğgi kaynağı olması bakımından hem dışsal koşulların hem de içsel (bireysel) özelliklerin üzerinde durulmasını gerekli kılmaktadır. Bu çalışmada içsel özellikler üzerinde durularak sosyo-demografik değişkenlerin iş güvencesizliği algısı üzerinde ne derece etkisi olduğu araştırılacaktır.

İş güvencesizliği konusu ile ilgili özellikle Türkçe yazın ve bunun içerisinde turizm yazını incelendiğinde yapılan araştırma sayısının sınırlı düzeyde olduğu söylenebilmektedir. Ayrıca iş güvencesizliği algısının sosyo-demografik değişkenlere göre nasıl değiştiği söz konusu olduğunda, araştırma sayısı daha da azalmaktadır. $\mathrm{Bu}$ nedenle araştırmanın yazına katkı sağlayacağı düşünülmektedir. Buna ek olarak araştırmanın, ilgili sektöre ve uygulayıcılara da fayda sağlayacağ 1 düşünülmektedir. Şöyle ki, iş güvencesizliği, birey, işletme ve nihayet toplum olmak üzere birçok kesime zararı dokunabilen oldukça yıpratıcı bir süreçtir. $\mathrm{Bu}$ noktada, iş güvencesizliği algısını etkileyebilen faktörlerin tespit edilmesi ile öncelikle iş güvencesizliği algısı daha yüksek olabilecek kişilere çeşitli destekler verilebilir ve bu zararlı sonuçlar minimize edilebilir.

Bu düşünceler ışığında ortaya çıkan araştırmada iki soruya yanıt aranacaktır:

- Otel çalışanlarının alan uygulaması yapılan dönem itibariyle iş güvencesizliği algısı hangi düzeydedir?

- Sosyo-demografik değişkenler, iş güvencesizliği algısını hangi yönde ve ne derece etkilemektedir?

\section{KAVRAMSAL ÇERÇEVE}

İş güvencesi kavramı, çalışanların işini güvence altına alıp, iş sözleşmesinin geçersiz veya keyfi fesihlere karşı korunması ve böylelikle istihdamın garanti altına alınması şeklinde tanımlanmaktadır (Polat, 2019a: 6). İş güvencesizliği ise bunun zit anlamlısı olarak işletme yönetimi ve psikoloji yazınında, bir çalışanın mevcut işinin devamlılığına yönelik bir tehdit "algısı" taşıması olarak tanımlanmaktadır (Seçer, 2007: 167).

İş güvencesizliği kavramı 1980'li yıllarda tek boyut olarak işin gelecekteki varlığına yönelik ortaya çıkan belirsizlik (Hellgren, Sverke ve Isaksson, 1999: 181) ve bunun yarattığ 1 endişe hali olarak tanımlanmıştır. Ancak kavram sonraki yıllarda daha geniş bir bakış açısı ile tanımlanmaya başlamıştır (Hellgren vd., 1999: 182). Böylelikle kavram, iş kaybına yönelik tehdit ile birlikte önemli iş özelliklerinin olumsuz yönde değişmesi (Greenhalgh ve Rosenblatt, 2010: 10) (kariyer ilerlemesi, iş ortamının fiziki koşulları, ücret ve ek ücretler gibi iş özellikleri) ve çalışanın işyerinde kendini etkileyecek gelişmelere müdahale gücünün olmayışı olarak tanımlanan "güçsüzlük" (Ashford, Lee ve Bobko, 1989: 805) durumlarını da içerecek şekilde tanımlanmaya başlanmıştır (Sverke, Hellgren ve Naswall, 2006: 243). Özetle, iş güvencesizliği kavramı son yıllarda yapılan 
çalışmalarda "iș kaybına yönelik algılanan tehdit (nicel iş güvencesizliği)", “iş özelliklerinin kötüleşme olasılığına yönelik algılanan tehdit (nitel iş güvencesizliği)" ve "güçsüzlük algısı" olmak üzere üç boyutta tanımlanmaktadır (Polat, 2019a: 8).

İş güvencesizliği kavramı, üç boyut altında incelendiği gibi objektif ve sübjektif olarak da incelenmektedir (Otluoğlu, 2014: 27). Buna göre iş güvencesizliğinin objektif yönüne vurgu yapan araştırmacılar (örneğin, Büssing, 1999), temel olarak dışsal koşullara odaklanmakta ve çalışanın şahsi özelliklerini göz ardı etmektedir (Sverke vd., 2006: 5). Örneğin ekonomik durgunluk/kriz dönemleri, örgütsel yapılanma faaliyetleri (küçülme, birleşme, özelleştirme vb.) ya da yeni bir teknolojik aracın çalışanların yerini alması ihtimalinin belirmesi gibi (Clark, 2005: 8) gözlemlenebilir ve somut faktörler objektif iş güvencesizliği kaynağı olabilmektedir. Ancak bazı araştırmalarda, objektif iş güvencesizliği kaynağ 1 olabilecek faktörler açısından benzer özelliklere sahip olan çalışanların farklı düzeylerde iş güvencesizliği algısına sahip olduğunun tespit edilmesi, bu varsayımların tekrar gözden geçirilmesini gerekli kılmıştır. Bu çerçevede iş güvencesizliğinin, sübjektif bir alg1 olarak incelenmesi gerektiği görüşü de yazında dile getirilmeye başlanmıştır (Otluoğlu, 2014: 27).

İş güvencesizliğinin sübjektif tanımı, çalışanların işlerini kaybetme korkusu yaşamaları ve işlerinin devamlılığ 1 konusundaki içsel kaygıları olarak yapılmaktadır (Atılgan, 2019: 4). Sübjektif iş güvencesizliğinin zihinsel bir algıyı içermesi, kuşkusuz ki, onun birçok farklı kişisel faktörün etkisi altında şekillenmesine ve böylelikle kişiden kişiye farklı düzeyde hissedilmesine kap1 aralamaktadır. Bir diğer deyişle, tüm çalışanların aynı riske sahip olduğu bir işyerinde, çalışanlar farklı düzeylerde iş güvencesizliği algısına sahip olabilirler (Nart, 2015: 72). Bu araştırmada da temel olarak bu konuya odaklanılmış ve iş güvencesizliği algısı sübjektif bir olgu olarak ele alınmış ve sosyodemografik yönden hangi özelliklerin iş güvencesizliği algısına etki ettiği araştırılmıştır.

İş güvencesizliği algısı oluşturabilecek durumlar, devamında işsizliğe ve dolaysıyla finansal gelirin kaybedilmesine yol açabileceğinden oldukça yıkıcı olabilmektedir. Bu konuda yapılmış araştırmalarda iş güvencesizliği algısının düşük düzeyde "iyi olma hali", yaşamdan memnuniyetsizlik, tükenmişlik, kaygı ve depresyon hali gibi psikolojik sağlı ile ilgili belirtilere ve çok sayıda fiziksel şikayete neden olduğu ifade edilmektedir (Sümer, Solak ve Harma, 2013: 77).
İş güvencesizliğinin bireysel sonuçları olduğu gibi örgütsel sonuçları da olabilmektedir. Bunlar arasında düşük örgütsel bağlılık, işten ayrılma niyetinde artış, örgütsel iklimde bozulma ve düşük iş tatmini gibi olumsuz sonuçlar vardır (Polat, 2019a: 40-43). Bu sonuçlar arasında çalışanların performans düşüklüğü yaşayabilecekleri ve örgütsel performansın da düşebileceği sıklıkla ifade edilmektedir. Bu çerçevede, iş güvencesizliği algısı yükselen çalışanların düşük kalitede çıktı üretebilecekleri (Probst, Stewart, Gruys ve Tierney, 2007: 482) ve işyerindeki güvenlik politikalarına uyum davranışlarının azalması nedeniyle iș kazalarına ve yaralanmalarına sebep olabilecekleri ifade edilmelidir (Lewchuk, Wolff, King ve Polanyi, 2003: 26). Ek olarak Staufenbiel ve König (2010: 103), iş güvencesizliği algısının artışı ile çalışanların iş kazalarını işletme yönetimine daha az bildirdiğine değinmektedir. Ayrıca işletme içerisinde iş sağlığı ve güvenliği ile ilgili konular, müşteri memnuniyeti ya da ürün kalitesi gibi değer görmüyorsa, iş kazaları ve yaralanmaları daha da artabilir. Tüm bunlar bireysel performansla birlikte örgütsel performansın düşmesine neden olabilecek faktörler olarak ifade edilebilir.

İş güvencesizliğinin bahse konu olumsuz sonuçları ve sübjektif yönü, bireysel özelliklerin iş güvencesizliği algısı üzerindeki etkisine dikkatle bakılmasını gerekli kılmaktadır. Böylelikle hangi özelliklerin iş güvencesizliği algısını etkilediğinin tespiti ile bunun azaltılmasi ya da ortadan kaldırılması için gerekli önlemler daha etkin bir şekilde alınabilecektir.

İş güvencesizliğinin çalışanların demografik özelliklerine göre nasıl farklılaştığı konusunda yazında ciddi sayıda araştırma yapılmıştır (Selvi ve Sümer, 2018: 4). Bunlar arasında önemli yer tutan değişkenlerden biri yaştır (Naswall vd., 2002: 70). $\mathrm{Bu}$ çalışmalar incelendiğinde tutarlı bir sonuç olduğunu söylemek güçtür. Çünkü bazı araştırmalarda iş güvencesizliği algısının yaş ile farklılaşmadığı ifade edilirken (Hellgren ve Sverke 2003; Sümer vd. 2013; Dede, 2017); baz1 araştırmalarda iş güvencesizliği algısının yaş ile arttığı ya da azaldığı tespit edilmiştir. Örneğin, Kinnunen ve Natti (1994), Naswall ve De Witte (2003), Dığın ve Ünsar (2010), Aslan (2011), Dereli (2012) ile Dursun ve Bayram (2013), yaşın artışı ile iş güvencesizliği algısının arttığını belirtmektedirler. Buna neden olabilecek birkaç argüman ileri sürülebilir. Birincisi, yaş ile birlikte aynı işletmedeki çalışma süresinin uzayabilmesi, çalışanın becerilerinin işletmenin faaliyet alanı ile sinırlanmasına neden olabilmekte (Sennett, 2017: 105-106) ve böylelikle bu çalışanların başka işletmede veya sektörde istihdamı zorlaşabilmektedir. Dolayısıyla yaşlıların mevcut 
işlerine bağımlılıkları artabilmektedir. İkincisi, genç çalışanların, yaşça büyük olanlara göre finansal veya çocuk bakımı gibi yükümlülüklerinin olmaması iş güvencesizliği algılarını azaltabilir. Üçüncüsü, gençlerin, dinamik yapıları nedeniyle iş kaybı karşısında kolay iş bulabilmeleri iş güvencesizliği algılarını artırmayabilir. Burada şunu da belirtmenin faydası var: Mevcut çalışmalarda yaş değişkeni ile ilgili tespit, $30-50$ yaş diliminin 30 yaş altı ile kıyaslanması sonucunda görülmektedir. Buradan hareketle 50 yaş üstü grupta iş güvencesizliği algısının daha da artması beklenir. Ancak 50 yaş üstü grupta $30-50$ yaş aralığına göre iş güvencesizliği algısı azalmakta ve beklentilere aykırı düşmektedir. Çünkü 50 yaş üzerindeki çalışanların genel olarak finansal yükümlülüklerinin ya da çocuklarına ait sorumlulukların azalmış/bitmiş olması gibi nedenler iş güvencesizliği algısını da azaltabilmektedir (De Witte, 1999: 162). Ayrica buna göre iş güvencesizliği algısı ile yaş değişkeninin ilişskisi hakkında akla gelebilecek ikinci bir sonuç, ilişkinin doğrusal değil, eğrisel bir yapıda olabileceğidir.

Karkoulian, Mukaddam, McCarthy ve Messara (2013) ise bahse konu çalışmaların aksine yaşın azalışı ile iş güvencesizliği algısının arttığını tespit etmiştir. Bu sonuç şu nedenden ileri gelebilir. Genç çalışanların bilgi-beceri bakımından yaşça büyüklere göre eksikliklere sahip olabilmesi, onları iş kaybı ihtimaline daha hassas k1labilmektedir. İkinci olarak, genç çalışanların sözleşme sürelerinin kısa olabilmesi de iş güvencesizliği algılarını artırabilir (Kinnunen, Makikangas, Mauno, De Cuyper ve De Witte, 2014: 245).

İş güvencesizliği ile ilişkisi araştırılan önemli bir diğer değişken de cinsiyettir (Naswall ve De Witte, 2003: 194). Kimi çalışmalarda (Kinnunen, Mauno, Natti ve Happonen, 1999; Rosenblatt, Talmud ve Ruvivo, 1999; Poyraz ve Kama, 2008; Dede, 2017) erkeklerin; kimilerinde ise (Kinnunen, Mauno, Natti ve Happonen, 2000; Naswall ve De Witte, 2003; Sümer vd., 2013) kadınların daha yüksek iş güvencesizliği algısına sahip oldukları tespit edilmiştir. Özellikle geleneksel toplumlarda kadınların ev işleri, erkeklerin ise ev geçindirme rolünü üstlenmeleri, işi erkekler açısından daha önemli hale getirmekte ve kayıp ihtimaline karşı iş güvencesizliği algısını artırabilmektedir (Naswall vd., 2002: 70). Kadınlar ise özellikle aileye gelir sağlayan tek kişi oldukları durumda (De Witte, 1999: 161) ya da iş yaşamında erkeklere göre bilgibeceri, kıdem vb. konularda dezavantajlı olduklarını düşünüyorlarsa daha yüksek iş güvencesizliği algısı taşımaktadırlar (Sümer vd., 2013: 145).

Medeni durum değiş̧keni de iş güvencesizliği algısını etkileyebilmektedir. Araştırmalar, evli çalışanların daha düşük düzeyde iş güvencesizliği algısı taşıdığı yönünde bulgular sunmaktadır (Naswall vd., 2002; Sümer vd., 2013; Yıldırım ve Yirik, 2014; Karacaoğlu, 2015). Bu sonuç, sosyal destek konusu ile ilişkilendirilerek açıklanabilir. Lim (1996), iş dışında alınabilecek sosyal desteğin iş güvencesizliği algısını azaltabileceğini ifade etmektedir. Evli çalışanlar bu desteği eşlerinden alabileceği için iş güvencesizliği algıları bekarlara kıyasen daha az olabilir. Esasında, evlilik bazı yükümlülükleri getirdiğinden iş kaybı ihtimalini daha endişe verici hale getirebilir. Ancak eşin desteği, bu endişeyi, stresi ve beraberinde iş güvencesizliği algısını da azalabilmektedir. Naswall ve De Witte (2003: 209)'nin araştırmasında ise eşin varlığının iş güvencesizliği ile ilişkili olduğu hipotezi desteklenmemiştir. $\mathrm{Bu}$ araştırmada sosyal destek eş sahibi olma ile ilişkilendirilmiş ve evli olmanın iş güvencesizliği algısı üzerinde herhangi bir farklılık oluşturmadığ 1 tespit edilmiştir.

Eğitim seviyesi, iş güvencesizliği algısını etkileyebilecek bir başka değişkendir. Düşük eğitim seviyesine sahip bireylerin günümüz iş piyasalarında aranan yetkinliklere sahip olabilmesi oldukça zordur. $\mathrm{Bu}$ nedenle bu kişilerin mevcut işlerine bağımlılıkları artabilmekte ve işlerini kaybettiklerinde daha zor iş bulabilmektedirler. Tüm bunlar, bu durumdaki çalışanların daha yoğun iş güvencesizliği algısı hissetmesine zemin hazırlamaktadır (Kinnunen ve Natti, 1994; Naswall vd., 2002: 77; Naswall ve De Witte, 2003: 208). Probst (1998) ile Green, Felstead ve Burchell (2000) ise eğitim seviyesinin artması ile iş güvencesizliği algısının arttığını ifade etmektedir. Ek olarak, Green vd. (2000: 856) yüksek eğitimli kişiler arasında iş kaybının daha sık rastlandığını ifade etmektedir. $\mathrm{Bu}$ ise iş kaybı durumunda benzer özelliklere sahip bir işi bulabilmeyi zorlaştırabilmektedir. $\mathrm{Bu}$ nedenle yüksek eğitim seviyesine sahip çalışanların iş güvencesizliği algısının artabileceği dile getirilmektedir (Dede, 2017: 21).

İşletmedeki çalışılan pozisyona göre iş güvencesizliği algısının nasıl değiştiği ile ilgili olarak Kovach (1995)'ın ifadeleri yol gösterici olabilir. Kovach (1995: 93-95)'in 1946-1995 yılları arasındaki 50 yıllık dönemi ele alan araştırmasına göre iş güvencesi, yönetici kademesinde çalışanlar açısından bir işte bulunması gereken en önemli ikinci gereklilik iken; alt kademe çalışanlar açısından dördüncü sırada gelmektedir. Yani yönetici kademesinde bulunan çalışanlar iş güvencesi konusuna daha duyarlıdır. Buna göre yönetici kademesindekilerin iş kaybı ihtimaline karşı daha hassas olabilecekleri ve daha yüksek iş güvencesizliği algısı taşıyabilecekleri söylenebilir. 
Nitekim Şenol (2010) ve Karacaoğlu (2015)'nun elde ettikleri sonuç bu yöndedir.

İş güvencesizliği algısına etki eden bir başka değişken olarak sözleşme tipi ele alınabilir. Sözleşme tipi "geçici süreli" ve "daimi sözleşme" olarak düşünülebilir. Yazında bu konu, iş güvencesizliği ile ilişkisi araştırılan önemli konulardan biridir. $\mathrm{Bu}$ çalışmalarda, geçici çalışanların işletmeye karşı aidiyet duygusu hissetmedikleri, işletme tarafından korunmadıkları ve ilk işten çıkarma operasyonlarında kendilerini risk altında gördükleri belirtilmektedir (Polat, 2019a: 29). Buna paralel olarak bu çalışanların iş güvencesizliği algıları daimi sözleşmeye sahip çalışanlara göre daha yüksek olabilir (Kinnunen ve Natti, 1994; Naswall vd., 2002; Parker, Griffin, Sprigg ve Wall, 2002; Naswall, Sverke ve Hellgren, 2005; Bustillo ve Pedraza, 2010; Polat, 2019a). Ancak bazı durumlarda geçici sözleşmeli çalışanların iş güvencesizliği algıları düşük de olabilmektedir. Bu çalışanların sözleşmeleri belirli bir süreyi kapsadığından, işin ne zaman son bulacağı bilinir (Sverke vd., 2006: 10). Bu sayede örneğin, mevcut işten ayrıldıktan sonra çalışabilecekleri bir iş olması gibi kendilerine alternatif oluşturabilirler. $\mathrm{Bu}$ bağlamda geçici çalışanların mevcut işlerindeki iş güvencesizliği algısı, daimi çalışanlara göre düşük olabilir. Nitekim Naswall ve De Witte (2003)'nin araştırması bunu teyit etmektedir.

Yazında, sektör deneyimi ya da iş tecrübesine göre de iş güvencesizliği algısının değişebileceğine ilişkin bulgular bulunmaktadır. Örneğin Aslan (2011) ve Şeker (2011), iş tecrübesindeki artış ile iş güvencesizliği puanında anlamlı bir düşüşün olduğunu gözlemlemiştir. Elman ve O'Rand (2002) ise $\mathrm{ABD}$ 'deki araştırmasında, iş tecrübesinin iş güvencesizliği algısı üzerinde anlamlı bir farklılık oluşturmadığını tespit etmiştir. Günümüz meslek yapılarındaki hızlı değişim ve çalışanların iş piyasasında tutunabilmek için temel becerilerini bile değiştirmek zorunda kalabilmesi iş ya da sektör tecrübesinin iş güvencesizliği algis1 üzerinde anlamlı bir etkisinin olmasını engelleyebilir. Çalışanların mevcut işlerini kaybetmeleri durumunda iş bulabilmeye karşı bakış açıları da iş güvencesizliği algısına etki edebilir. Sektör tecrübesi arttıkça bireylerin, çalıştıkları sektörde istenen becerilere sahip olmaları beklenir. Böylelikle çalışanlar, mevcut işleri son bulsa bile hemen başka bir iş bulabileceğini düşünürse daha az iş güvencesizliği algısına sahip olabilir. Nitekim, Seçer (2007)'in istihdam edilebilirlik algısının nicel iş güvencesizliği üzerinde negatif etkileri olduğuna dair bulgusu, buna destekleyici bir argüman olarak ileri sürülebilir.

\section{YÖNTEM}

\subsection{Araştırmanın Amacı ve Önemi}

$\mathrm{Bu}$ araştırmanın amacı, otel çalışanlarının sahip oldukları iş güvencesizliği algısının düzeyini ve sosyo-demografik değişkenlerin iş güvencesizliği algısını nasıl etkilediğini tespit etmektir. Kuramsal kısımda değinildiği üzere iş güvencesizliği, artan önemi ile son yıllarda çok sayıda araştırmaya konu edilmektedir. Ancak turizm yazınında konunun yeterince araştırıldığı söylenemez. Özellikle bireyden bireye değişen yapısı nedeniyle sosyodemografik değişkenlerin iş güvencesizliği üzerinde önemli etkileri olabileceği düşünülmektedir. $\mathrm{Bu}$ araştırmada yapılacak tespitlerle konu hakkında hem yazındaki boşluğa katkı sağlamak hem de işletmelere çeşitli öneriler getirmek planlanmaktadır. $\mathrm{Bu}$ nedenle araştırmanın önem taşıdığı söylenebilir.

\subsection{Evren ve Örneklem}

Araştırmanın evrenini Antalya ilindeki otel çalışanları oluşturmaktadır. Sosyal Güvenlik Kurumu'nun 2018 yılı verilerine göre Antalya'daki (sigortalı) otel çalışanlarının sayısı 66.019'dur (Sosyal Güvenlik Kurumu [SGK], 2020). Bu evren büyüklüğüne ulaşmak, maliyet, zaman veya kontrol güçlügü gibi nedenlerle imkan dâhilinde olmadığından kolayda örnekleme yöntemine göre örneklem alınmıştır. Araştırmada kolayda örnekleme yöntemi kullanılmasının bir diğer nedeni, otel işletmelerinin anketin uygulandığ dönemde oldukça yüksek bir yoğunlukta çalışmaları nedeniyle çalışanlara tesadüfi örnekleme yoluyla ulaşmanın mümkün olmamasıdır.

Örneklem büyüklüğü \%95 güvenirlik düzeyinde 381 olmalıdır (Sekaran, 2003: 294). Anket formu, 2019 yılının Eylül ayı içerisinde 750 çalışan ile ve yüz yüze görüşülerek uygulanmış, geriye dönen 707 anket formundan 653 tanesi değerlendirmeye alınabilmiştir.

\subsection{Veri Toplama Aracı}

Kuramsal ve alan incelemesi olarak iki aşamada gerçekleştirilen bu araştırmada öncelikle yazın taraması ile konu hakkında fikir sahibi olmak amaçlanmış, ardından birincil verilerin elde edilebilmesi için otel çalş̧anları ile yüz yüze görüşülerek anket uygulaması yapılmıştır. Anket formu iki bölümden oluşmaktadır. İlk bölümde kişisel bilgi formu yer alırken; ikinci bölümde Polat (2019a)'ın çalışmasından uyarlanan ve 11 sorudan oluşan iş güvencesizliği ölçeği yer almaktadır. Ölçek, nitel iş güvencesizliği, nicel iş güvencesizliği ve güçsüzlük olmak üzere üç 
boyuttan oluşmaktadır. Ölçekteki ifadeler 5'li Likert derecelendirmesine sahiptir (1: Kesinlikle Katılmıyorum; 5: Kesinlikle Katılıyorum).

\subsection{Verilerin Analizi}

Veriler, IBM SPSS 21.0 ve Lisrel 8.80 paket programları kullanılarak analiz edilmiştir. Çalışanların demografik özellikleri frekans ve yüzde dağılımları ile betimlenmiştir. Verilerin normal dağılım şartını sağlayıp sağlamadıklarının kontrolü için çarpıklık ve basıklık değerleri kontrol edilmiş; güvenirlik içsel tutarlık analizi; geçerlik, yap1 geçerliği ile sağlanmaya çalışılmıştır. Değişkenleri daha sağlıklı belirleyebilmek amacıyla, doğrulayıcı faktör analizi (DFA) yapılmıştır. Çalışanların iş güvencesizliği puanını hesaplayabilmek için ölçek ortalaması hesaplanmış; bağımsız değişkenlerin bağımlı değişken üzerindeki etkisi ikili lojistik regresyon analizi ile belirlenmiştir.

Lojistik regresyon analizi, değişkenlerin evet-hayır, olumlu-olumsuz, var-yok, başarıl1-başarısız şeklinde sürekli olmayan, kategorik verileri içermesi durumunda bağımlı ve bağımsız değişkenler arasındaki neden-sonuç ilişkilerinin incelenmesinde kullanılmaktadır (Peng ve So, 2002: 33). Çokluk (2010: 1368), lojistik regresyonu analizinde bağımsız değişkenlerin dağılımına ilişkin herhangi bir varsayımın karşılanmasını gerektirmediğini ifade ederken; Can (2018: 309313) bağımsız değişkenler arasında yüksek düzeyli bir korelasyon bulunmaması, uç değerlerin olmaması ve en az aralık ölçeğinde sürekli olan bağımsız değişkenler ile bağımlı değişkenin logit dönüşümü arasında doğrusal bir ilişkinin olması şeklinde üç varsayımdan bahsetmektedir.

$\mathrm{Bu}$ araştırmada, ikili lojistik regresyon analizi kullanılacaktır. Bağımlı değişkenin iki seçenekli bir kategorik değişken olması durumunda "İkili Lojistik Regresyon Analizi (Binary Logistic Regression Analysis)" kullanılmalıdır (Çokluk, 2010: 1362). Bu nedenle ilk olarak araştırmada bağımlı değişken olan iş güvencesizliğinin alt boyutları iki sonuçlu olacak şekilde yeniden kodlanmıştır. Polat (2019b)'ın izlediği yönteme benzer şekilde, iş güvencesizliği ölçeğinden aritmetik ortalamanın bir standart sapma üstü puan alanlar, yüksek iş güvencesizliği algısına sahip çalışanlar (YİG); bir standart sapma altı puan alanlar ise düşük iş güvencesizliği algısına sahip çalışanlar (DİG) olarak belirlenmiştir. DİG 0 (sıfır) ile YİG 1 (bir) ile kodlanmıştır. Buna göre DİG referans kategoriyi, YİG hedef kategoriyi oluşturmaktadır. İş güvencesizliği algısına etki edebileceği düşünülen bağımsız değişkenler ise şu şekilde kodlanmıştır: $\bullet$

$\bullet$

Medeni hal (0: Evli; 1: Bekar)

Yaş (1: 16-20; 2: 21-30; 3: 31-40; 4: 4150; 5: 51 ve üstü)

- Eğitim seviyesi (1: İlköğretim; 2: Ortaöğretim; 3: Önlisans; 4: Lisans)

- $\quad$ Aylık gelir (0: 0 - 2300 TL; 1: 2301 TL ve üstü)

- $\quad$ Turizm gelirinin bütçedeki yeri (0: Tek gelir kaynağı turizm; 1: Gelirin bir kısmı turizmden)

- $\quad$ İşletmedeki görev (0: Yönetici/Şef; 1: Alt kademe çalışan)

- $\quad$ Sektör deneyimi (1: 1-2 y1l/sezon; 2: 3-4 y1l/sezon; 3: 5 yıl/sezon ve üzeri)

- Daha önce aynı işletmede çalıșma durumu (0: Evet; 1: Hayır)

- Çalışma biçimi (0: Tüm yıl çalışan; 1: Sezonluk çalışan)

- $\quad$ İş sözleşmesinin varlığı (0: Var; 1: Yok)

- $\quad$ İş kaybı durumunda iş bulabilme durumu (1: Hemen yeni bir iş bulabilirim; 2: Zorlanarak yeni bir iş bulabilirim; 3: Yeni bir iş bulamam)

Analiz sonrasında görülecek tablolardaki B değeri, bağımsız değişkenlerin, bağımlı değişken üzerindeki pozitif ya da negatif etkisini gösteren regresyon katsayısıdır. Negatif işaret olayın görülme olasılığının azaldığ 1 , pozitif işaret arttı̆̆ șeklinde yorumlanmaktadır. Exp (ß) değeri ise diğer değişkenler sabitken, bağımsız değişkende görülecek bir birimlik artışın olayın görülme olasılığındaki artışı belirtmektedir (Çokluk, 2010: 1383).

\section{BULGULAR}

Araştırmaya katılan bireylerin demografik özellikleri Tablo 1'de sunulmuștur. Katılımcılar ağırlıklı olarak erkek $(\% 63,7)$, bekar (\%56), 21-30 yaş aralığında $(\% 44,7)$, ortaöğretim düzeyinde eğitime sahip $(\% 50,7), 0-2300$ TL gelire sahip $(\% 79,3)$, alt kademe çalışan $(\% 84,4), 1-2$ yıl/sezon sektör deneyimine sahip $(\% 44,1)$, daimi çalışandır $(\% 58,2)$. Katılımcıların \%62,4'ü iş sözleşmesinin olmadığını ifade ederken; \%85,9'u turizmden elde ettiği gelirin tek gelir kaynağ 1 olduğunu ifade etmektedir. Ayrica katılımciların \%65,8'i mevcut işletmede daha önce çalışmadığını ifade etmiştir. Son olarak katılımcılara mevcut işin kaybı durumunda yeni iş bulabilme konusundaki soruya $\% 73,5$ oranında hemen yeni bir iş bulabilirim şeklinde yanıt vermiştir. 
Tablo 1: Katılımcıların Demografik Özelliklerine Göre Dağılımı

\begin{tabular}{|c|c|c|c|c|c|c|c|}
\hline \multicolumn{2}{|c|}{ Değişkenler } & \multirow{2}{*}{$\frac{\mathbf{n}}{229}$} & \multirow{2}{*}{$\frac{\%}{35,1}$} & \multicolumn{2}{|c|}{ Değişkenler } & \multirow{2}{*}{$\frac{\mathbf{n}}{288}$} & \multirow{2}{*}{$\frac{\%}{44,1}$} \\
\hline \multirow{2}{*}{ Cinsiyet } & Kadın & & & \multirow{4}{*}{$\begin{array}{c}\text { Sektör } \\
\text { Deneyimi }\end{array}$} & $1-2$ y1l/sezon & & \\
\hline & Erkek & 416 & 63,7 & & 3-4 yil/sezon & 175 & 26,8 \\
\hline \multirow{2}{*}{ Medeni Hal } & Evli & 274 & 42 & & $5 \mathrm{yll} / \mathrm{sezon}$ ve & \multirow{2}{*}{177} & \multirow{2}{*}{27,1} \\
\hline & Bekar & 366 & 56 & & üzeri & & \\
\hline \multirow{4}{*}{ Yaş } & $16-20$ & 48 & 7,4 & \multirow{3}{*}{$\begin{array}{c}\text { Turizm } \\
\text { gelirinin } \\
\text { bütçedeki } \\
\text { yeri }\end{array}$} & $\begin{array}{c}\text { Tek gelir } \\
\text { kaynağım turizm }\end{array}$ & 561 & 85,9 \\
\hline & $21-30$ & 292 & 44,7 & & Gelirimin bir & \multirow{2}{*}{81} & \multirow{2}{*}{12,4} \\
\hline & $31-40$ & 142 & 21,7 & & kısmı turizmden & & \\
\hline & 41 ve üzeri & 168 & 25,8 & \multirow{5}{*}{$\begin{array}{l}\text { Daha önce } \\
\text { aynı } \\
\text { işletmede } \\
\text { çalışma } \\
\text { durumu }\end{array}$} & \multirow{2}{*}{ Evet } & \multirow{2}{*}{203} & \multirow{2}{*}{31,1} \\
\hline \multirow{4}{*}{$\begin{array}{l}\text { Eğitim } \\
\text { Seviyesi }\end{array}$} & İlköğretim & 124 & 19 & & & & \\
\hline & Ortaöğretim & 331 & 50,7 & & \multirow{3}{*}{ Hayır } & \multirow{3}{*}{430} & \multirow{3}{*}{65,8} \\
\hline & Önlisans & 87 & 13,3 & & & & \\
\hline & Lisans & 107 & 16,4 & & & & \\
\hline \multirow[b]{2}{*}{ Aylık Gelir } & $0-2300 \mathrm{TL}$ & 518 & 79,3 & \multirow{2}{*}{$\begin{array}{l}\text { Çalışma } \\
\text { Biçimi }\end{array}$} & Daimi çalışan & 380 & 58,2 \\
\hline & $\begin{array}{l}2301 \mathrm{TL} \text { ve } \\
\text { üstü }\end{array}$ & 131 & 20,1 & & Sezonluk çalışan & 273 & 41,8 \\
\hline \multirow{5}{*}{$\begin{array}{l}\text { İşletmedeki } \\
\text { görev }\end{array}$} & Yönetici/Şef & 100 & 15,3 & \multirow{2}{*}{$\begin{array}{c}\text { İş } \\
\text { sözleşmesinin } \\
\text { varlığı }\end{array}$} & Var & 240 & 36,9 \\
\hline & $\begin{array}{c}\text { Alt kademe } \\
\text { çalışan }\end{array}$ & 551 & 84,4 & & Yok & 407 & 62,4 \\
\hline & & \multirow{3}{*}{\multicolumn{3}{|c|}{$\begin{array}{l}\text { Mevcut işin kaybı } \\
\text { durumunda yeni bir iş } \\
\text { bulabilme durumu }\end{array}$}} & $\begin{array}{c}\text { Hemen yeni bir iş } \\
\text { bulabilirim }\end{array}$ & 480 & 73,5 \\
\hline & & & & & $\begin{array}{c}\text { Zorlanarak yeni } \\
\text { bir iş bulabilirim }\end{array}$ & 65 & 10 \\
\hline & & & & & $\begin{array}{l}\text { Yeni bir iş } \\
\text { bulamam }\end{array}$ & 105 & 16,1 \\
\hline
\end{tabular}

Veri analizine geçmeden önce normal dağılım şartının kontrolü için çarpıklık ve basıklık değerlerine bakılmıştır. Buna göre verilerin çarpıklık değerlerinin $-0,369$ ile 1,650 arasında, basıklık değerlerinin 2,194 ile $-0,511$ arasında yer aldığı görülmüş ve normal dağılım şartının sağlandığı anlaşılmıştır (Kline, 2016: 77).
Araştırmada kullanılan ölçeğin yapı geçerliğini test etmek amaciyla düzenlenen DFA sonucunda Polat (2019a)'ın çalışmasına uygun olacak şekilde üç boyutlu bir yap1 elde edilmiştir. Analiz sonucunda uyum iyiliği değerlerinin $(\chi 2 / \mathrm{df}=3,37$; RMSEA $=0,06 ; \quad$ SRMR $=0,042 ; \quad$ GFI $=0,96$ $\mathrm{AGFI}=0,94 \mathrm{NFI}=0,98 \mathrm{CFI}=0,99)$ iyi ya da kabul

Tablo 2: İş Güvencesizliği Ölçeğine Yönelik Faktör Analizi Sonucu

\begin{tabular}{|c|c|c|c|c|}
\hline Örtük Değişkenler ve Maddeler & $\begin{array}{r}\text { Faktör } \\
\text { Yüküi } \\
\end{array}$ & CA & $\mathbf{C R}$ & AVE \\
\hline Nicel İş Güvencesizliği $(\bar{X}=1,78 ;$ S.S. $=0,89)$ & & 0,65 & $\mathbf{0 , 7 8}$ & 0,64 \\
\hline İfade1 & 0,80 & & & \\
\hline İfade3 & 0,71 & & & \\
\hline Nitel İş Güvencesizliği ( $\bar{X}=2,10 ;$ S.S. $=0,89$ ) & & 0,87 & $\mathbf{0 , 8 8}$ & $\mathbf{0 , 5 5}$ \\
\hline İfade 8 & 0,79 & & & \\
\hline İfade9 & 0,79 & & & \\
\hline İfade7 & 0,78 & & & \\
\hline İfade10 & 0,78 & & & \\
\hline İfade11 & 0,68 & & & \\
\hline İfade12 & 0,62 & & & \\
\hline Güçsüzlük ( $\bar{X}=3,45 ;$ S.S. $=1,26)$ & & 0,90 & 0,90 & 0,76 \\
\hline İfade14 & 0,88 & & & \\
\hline İfade15 & 0,87 & & & \\
\hline İfade13 & 0,85 & & & \\
\hline
\end{tabular}


Tablo 3: Fornell-Larcker Ölçütü

\begin{tabular}{lccc}
\hline Değişkenler & $\mathbf{1}$ & $\mathbf{2}$ & $\mathbf{3}$ \\
\hline 1. Nicel iş güvencesizliği &, $80^{*}$ & & \\
2. Nitel iş güvencesizliği &, 58 &, $74^{*}$ & \\
3. Güçsüzlük &,- 35 &,- 53 & $0,87^{*}$ \\
\hline
\end{tabular}

edilebilir uyum indeksleri değer aralığı içerisinde olduğu gözlenmiştir (Schermelleh-Engel, Moosbrugger ve Müller, 2003: 52). Tablo 2'de iş güvencesizliği ölçeğine yönelik faktör yükleri, Cronbach Alfa katsayıları (CA), bileşik güvenirlik değerleri (CR) ve açılkanan ortalama varyans değerleri (AVE) görülmektedir. Buna göre örtük değişkenlerin maddelerine ilişkin faktör yükleri 0,30'dan (Seçer, 2017: 188), faktörlerin CR değerleri 0,70'ten; AVE değerleri ise 0,50'ten yüksek olmalıdır. CR ve AVE değerlerine ait sınır değerler, yakınsama geçerliğinin sağlanması için gerek şartlardır (Sop, 2019: 215). Tablo 2'de yer alan sonuçlar ölçeğin yakınsama geçerliğinin ve güvenirliğin sağlandığını göstermektedir.

Faktör yapıları arasındaki ayrışma geçerliği ise Fornell-Larcker Ölçütü (FLÖ) ile incelenmiştir. FLÖ'ye göre bir yapıya ait AVE değerinin karekökü, diğer yapılar ile bu yapı arasındaki korelasyon katsayılarından yüksek olmalıdır (Sop, 2019: 215). Tablo 3'te (*) ile gösterilen değerler, diğer yapılar ile ilgili yap1 arasındaki korelasyon katsayılarından yüksektir. Bu durum, ölçekteki yapılar arasındaki ayrışma geçerliğinin sağlandığının delilidir.

Araştırma sorularından ilki olan otel çalışanlarının sahip olduğu iş güvencesizliği düzeyinin ölçülebilmesi için ölçeğin aritmetik ortalaması hesaplanmıştır $(\bar{X}=2,41 \pm 0,51)$. Elde edilen sonuçlara göre alan uygulaması yapılan dönem itibariyle otel çalışanlarının düşük seviyede iş güvencesizliği algısı taşıdıkları söylenebilmektedir.

Araştırmada, sosyo-demografik değişkenlerin iş güvencesizliği üzerindeki etkisinin tespiti için ikili lojistik regresyon analizi yapılmıştır. Bunun için

Tablo 4: Lojistik Regresyon Modelindeki Değişkenler ve Katsayıları

\begin{tabular}{|c|c|c|c|c|c|}
\hline & B (sh) & Wald & df & Sig. & $\operatorname{Exp}(B)(\% 95$ GA) \\
\hline $\operatorname{Cinsiyet}(1)^{* * *}$ & ,763 (,37) & 4,323 & 1 & ,038 & $2,145(1,045-4,404)$ \\
\hline Medeni Hal(1) &,$- 034(, 43)$ &, 006 & 1 & ,936 & ,967 \\
\hline Yaş & ,095 (,27) &, 130 & 1 & ,719 & 1,099 \\
\hline Eğitim Durumu &,$- 157(, 18)$ &, 828 & 1 &, 363 &, 855 \\
\hline Aylık Gelir(1)* &,$- 815(, 47)^{*}$ & 3,084 & 1 & ,079 & ,443 (,178 - 1,099) \\
\hline $\begin{array}{l}\text { Turizm gelirinin bütçedeki } \\
\text { yeri(1) }\end{array}$ &, $519(, 47)$ & 1,255 & 1 & ,263 & 1,681 \\
\hline İşletmedeki görev(1) &, $217(, 46)$ &, 224 & 1 & ,636 & 1,242 \\
\hline Sektör Deneyimi & ,459 (,29) & 2,534 & 1 &, 111 & 1,583 \\
\hline $\begin{array}{l}\text { Daha önce aynı işletmede } \\
\text { çalışma durumu(1) }\end{array}$ & ,427 (,39) & 1,234 & 1 &, 267 & 1,533 \\
\hline Çalışma Biçimi(1) &,$- 282(, 40)$ &, 503 & 1 &, 478 & ,755 \\
\hline İş sözleşmesi(1) &,$- 287(, 34)$ & ,718 & 1 & ,397 &, 750 \\
\hline $\begin{array}{l}\text { İş kaybı durumunda iş bulabilme } \\
\text { durumu }\end{array}$ & ,064 (,22) & ,087 & 1 & ,768 & 1,066 \\
\hline Sabit & $-1,024(1,1)$ &, 771 & 1 &, 380 & ,359 \\
\hline Varyans Açıklama Oranı & & & \multicolumn{3}{|c|}{ Cox ve Snell $=\% 12 ;$ Nagelkerke $=\% 16$} \\
\hline Ki-kare & & & & & 22,067 \\
\hline Hosmer \&Lemeshow & & & & & 551 \\
\hline Omnibus sig. & & & & & ,037 \\
\hline
\end{tabular}


öncelikle analiz için gerekli varsayımların kontrolü gerçekleştirilmiştir. $\mathrm{Bu}$ kapsamda, bağımsız değişkenler arasında yüksek düzeyli bir korelasyon olmadığı gözlenmiş̧ir. Bir diğer varsayım olan en az aralık ölçeğinde sürekli olan bağımsız değişkenler ile bağımlı değişkenin logit dönüşümü arasında doğrusal bir ilişkinin olmaması varsayımının, bu araştırmada sürekli bağımsız değişkenin bulunmaması nedeniyle karşılanması gerekmemektedir. Son olarak ölçekteki uç değerler kontrol edilmiş ve bu anketler veri setinden çıarılmıştır.

İş güvencesizliği algısını artırması ya da azaltması bakımından, demografik değişkenlerin etkisini göstermek amaciyla kurulan lojistik regresyon denklemi sonucunda modelin istatistiksel olarak anlamlı olduğu görülmektedir $\left(\mathrm{x}^{2}=22,067 ; \mathrm{p}<0,05\right)$. Hosmer ve Lemeshow Uyum İyiliği Testi sonrasında ortaya çıkan $\mathrm{p}=0,551>0,05$ sonucu da modelin anlamlılığına katkı yapmaktadır. Model, Nagelkerke $\mathrm{R}^{2}$ katsayısına göre bağımlı değişkendeki değiş̧imin \%16'sını açıklamaktadır. $\mathrm{Bu}, \quad$ kurulan modeldeki sosyo-demografik değişkenlerin, iş güvencesizliği algısındaki değişimin \%16'sını açıkladığı anlamında da yorumlanabilir (Tablo 4). Ayrica model, katılımcıların \%63,4'ünü doğru kategorilerde sinıflandırmaktadır.

Elde edilen sonuçlara göre cinsiyet (\%5 anlamlılık seviyesinde) ve aylık gelir (\%10 anlamlılık seviyesinde), çalışanların iş güvencesizliği algısına etki eden iki sosyo-demografik değişkendir. Cinsiyet açısından erkeklerin iş güvencesizliği algısının, kadınlara göre yaklaşık 2,15 kat daha fazla olduğu görülmektedir. Aylık gelir bakımından ise alt gelir grubunda olan çalışanların (burada 02300 TL arasında gelire sahip olanlar) iş güvencesizliği algısı, üst gelir grubundakilere göre yaklaşık olarak 2,25 kat $(1 / 0,443)$ daha yüksektir.

\section{SONUÇ VE TARTIȘMA}

İş güvencesi, çalışanlar tarafindan özellikle Türkiye gibi yüksek işsizlik oranlarının görüldüğü ülkelerde, bir işte bulunması gereken en öncelikli özelliklerinden biri olarak talep edilmektedir. Buna rağmen iş güvencesi özellikle 1970‘li yıllardan itibaren, tüm dünyada görülen politik, ekonomik, kamusal ve örgütsel değişiklikler neticesinde zayıflamış ve iş güvencesizliği özellikle de işsizlik oranlarının yüksek olduğu ülkelerde genel-geçer bir durum haline gelmiştir. Bunun sonucunda iş güvencesizliği, iş çevrelerinde ve toplumda artan bir şekilde konuşulmaya, tartışılmaya, üzerinde çeşitli araştırmalar yapılmaya ve politikalar üretilmeye başlanmıştır. Ancak Türkçe yazın ve özellikle turizm yazını açısından konu, çok ilgi çekmemiş ve yapılan araştırma sayısı sınırlı düzeyde kalmıştır.

İş güvencesizliği, öncelikli olarak çalışanların dışında gelişen olaylar neticesinde artış göstermiş ancak ilk ve en belirgin etkileri çalışanlara yönelik ortaya çıkmıştır. Turizm sektörünün dişsal olaylara karşı oldukça duyarlı olan yapısı ve sektörde görülen yüksek işgören devir hızı ise çalışanların iş güvencesizliğini çok daha derinden hissetmesine yol açmaktadır. Buna ek olarak, iş güvencesizliğinin çevresel etkenlerle birlikte bireysel özelliklerden etkilenen ve bu özelliklere göre şekil alabilen bir yönü de bulunmaktadır. İşte bu araştırmada temel olarak bu konuya odaklanılmış ve otel çalışanlarının iş güvencesizliği algılarının düzeyini belirleyebilmek ve sosyodemografik özelliklerin iş güvencesizliği algısını nasıl etkilediğini tespit edebilmek amaçlanmıştır.

Araştırmadan elde edilen sonuçlara göre otel çalışanlarının iş güvencesizliği algısının ortalama puanı 2,41 olarak tespit edilmiştir. Bu sonuca göre, alan uygulaması yapılan dönemle sınırlı olmak kaydıyla, otel çalışanlarının iş güvencesizliği algılarının düşük seviyede olduğunu söylemek mümkündür. İş güvencesizliği algısının dışsal ve içsel kaynakların ayrı ayrı ya da ortak etkisi ile ortaya çıkabilmesi nedeniyle dönemsellik konusuna özel bir vurgu yapmak gerekmektedir. Bu açıdan, araştırma yürütülen bölgede, araştırma yapılan dönemde otelcilik sektöründe görülen yüksek talep ve yüksek doluluk oranları iş güvencesizliği algısının düşük olarak gerçekleşmesindeki neden olarak ileri sürülebilir. Zira konu hakkında turizm sektöründe araştırmalar yapmış olan Şenol (2010) otel çalışanlarının iş güvencesizliği puanını 3,36; Darvishmotevali, Arasli ve Kilic (2017) ise 3,90 olarak tespit etmiştir. Bu araştırmadaki sonuç ile otel çalışanları açısından dönemsel koşulların, iş güvencesizliği algısını azaltıcı yönde etkileri olduğu ifade edilebilir.

Çevresel koşullar çalışanların iş güvencesizliği algısını etkilese de bunun bir de sübjektif yönü olduğunu unutmamak gerekir. $\mathrm{Bu}$ nedenledir ki, koşulları tamamen aynı olan çalışanların bile iş güvencesizliği algıları birbirinden farklı olabilmektedir. $\mathrm{Bu}$ farklılı̆̆ ortaya çıkarabilecek faktörlerden biri, çalışanların çevrelerindeki olayları yorumlama biçimlerini ve dolayısıyla bunlardan çıkardığı sonuçları etkileyebilen sosyo-demografik özellikleridir. Bu araştırmada elde edilen sonuçlara göre, iş güvencesizliği algısındaki farklılığı ortaya çıkarabilecek sosyo-demografik değişkenlerden birisi çalışanların cinsiyetleridir. Buna göre erkeklerin kadınlara göre yaklaşı 2,15 kat daha fazla iş güvencesizliği algısı taşıdıkları tespit 
edilmiştir. Bu sonuç, ülkemizdeki sosyo-kültürel yapıyla da uyumlu olarak, ev geçimini sağlama yükümlülüğünün -genelde- erkekler tarafindan üstlenilmesi ile ilişkilendirilebilir. Bunun sonucunda erkekler açısından iş kaybı yaşama ihtimali daha fazla endişe ve kaygı verici bir hale gelmiş olabilir. Ayrıca bu sonuç yazındaki önceki çalışmalar ile de uyumludur (Kinnunen vd., 1999; Rosenblatt vd., 1999; Poyraz ve Kama, 2008; Dede, 2017).

Analizler sonucunda iş güvencesizliği algısını etkileyen bir diğer değişkenin aylık gelir olduğu tespit edilmiştir. Buna göre, araştırmada alt gelir grubu olarak sınıflanan 0-2300 TL grubunun iş güvencesizliği algıs1, üst gelir grubuna göre yaklaşık olarak 2,25 kat daha yüksektir. Ferrie, Shipley, Newman, Stansfeld ve Marmot, (2005) ile Berglund vd. (2014) de aylık gelir düştükçe iş güvencesizliği algısının arttığını tespit etmişlerdir. Ayrica Ferrie vd. (2005) bu durumu cinsiyetler açısından ayrı ayrı ele almış ve bu durumun erkekler açsından geçerli olduğunu tespit etmiştir. Aylık geliri düşük olanların genelde düşük beceri gerektiren işlerde çalıştıkları ve mavi yakalı çalışan grubunda yer aldıkları söylenebilir. $\mathrm{Bu}$ grubun mevcut işleri haricinde başka finansal kaynaklarının olması, Türkiye açısından pek de mümkün değildir. Ek olarak, bu grupta yer alanlar yüksek düzeyde finansal yükümlülüklere de sahipse, işten çıkarılmaları yıkıcı sonuçları doğurabilecektir. İşte bu ihtimallere karşılık, bu grubun iş güvencesizliği algısı diğer gruba nazaran daha yüksek olabilir.

İlgili analizler, bu çalışma özelinde bazı sosyodemografik değişkenlerin iş güvencesizliği algısı üzerinde anlamlı bir etkiye sahip olmadığını ifade etmeye imkan tanımaktadır. Bu değişkenler şu şekildedir: Medeni hal, yaş, eğitim seviyesi, turizm gelirinin bütçedeki yeri, işletmedeki görev, sektör deneyimi, daha önce aynı işletmede çalışma durumu, çalışma biçimi, iş sözleşmesinin varlığı, iş kaybı durumunda iş bulabilme durumu.

İş güvencesizliğinin zararlı etkilerinin azaltılması için öncelikle hangi sosyo-demografik özelliklere sahip çalışanların daha yüksek iş güvencesizliği algısına sahip olduklarının tespit edilmesi önem arz etmektedir. $\mathrm{Bu}$ araştırmada ortaya çıkan sonuçlara göre turizm sektörü çalışanları açısından erkek ve alt gelir grubunda yer alanların, diğer gruplara göre daha yüksek düzeyde iş güvencesizliği algısı taşıdığı söylenebilmektedir. Bu nedenle işletmeler, turizm sektöründe de etkileri hissedilmeye başlanan çeşitli kriz dönemlerinde bu gruplara, iş güvencesizliği sürecine karşı psikolojik dayanıklılığın nasıl sağlanacağı ve bunun nasıl sürdürülebilir kılınacağı gibi başlıklara sahip bilinçlendirme çalışmaları yapabilir. Ayrıca bu eğitimlerde, çalışanların beceri gelişimlerinin sağlanması ve dolayısıyla istihdam edilebilirlik algılarının artırılması amacıyla iş mülakatlarına hazırlanma ya da kariyer gelişimlerini sağlayabilecek çeşitli seminerler de konu edilebilir.

Bahse konu öneriler belki ilk bakışta, işletme maliyetlerini artıran ve uygulanması zor olan öneriler olarak değerlendirilebilir. Ancak unutulmamalıdır ki, eğitim faaliyetlerinin uzun vadede ortaya çıkan faydaları, bu maliyetlerin üzerinde olmaktadır. Ek olarak, bu eğitimlerin iş güvencesizliğinin azaltılmasına olan katkısının yanında, çalışanların performansını artırdığı, hatta kimi zaman buna örgün eğitimden bile daha fazla katk1 sağladığ 1 da (Pfeffer, 1995: 13) söylenebilir.

$\mathrm{Bu}$ araştırmanın bazı kısıtları bulunmaktadır. Bunlardan birisi, araştırmanın kesitsel bir yapıda olmasıdır. Belirli bir zaman dilimini kapsayan kesitsel araştırmalar, ancak o zaman dilimindeki ilişkileri tespit edebilmekte ya da betimleyebilmektedir. $\mathrm{Bu}$ nedenle konu hakkında boylamsal (izlemeye yönelik) araştırmalar yapılması, iş güvencesizliği algısındaki seyrin takibine imkân tanıyacaktır. Bir diğer kısıt örnekleme yöntemi ile ilgilidir. Araştırmada kolayda örnekleme yöntemi kullanılması nedeniyle ulaşılan sonuçların evrene genellenmesi noktasında dikkatli davranmak gerekmektedir.

\section{ETİK BEYANATI}

Destek Bilgisi: Bu çalışma, kamu, ticari veya kar amacı gütmeyen kuruluşlar gibi herhangi bir organizasyondan destek almamıştır.

Çıkar Çatışması: Tüm yazarlar adına, sorumlu yazar çıkar çatışması olmadığını belirtir.

Etik Onay: İnsan katılımcıları içeren çalışmalarda gerçekleştirilen tüm prosedürler, kurumsal ve / veya ulusal araştırma komitesinin etik standartlarına ve 1964 Helsinki deklarasyonuna ve daha sonraki değişikliklerine veya karşılaştırılabilir etik standartlara uygundur.

Bilgilendirilmiş Onam Formu: Çalışmaya katılan tüm bireysel katılımcılardan bilgilendirilmiş onam formu alınmıştır. 


\section{KAYNAKÇA}

Ashford, S., Lee, C. \& Bobko, P. (1989). Content, causes, and consequences of job insecurity: a theory-based measure and substantive test. The Academy of Management Journal, 32(4), 803-829.

Aslan, K. (2011). Çalışanlarda iş güvencesizliği ve işini kaybetme kaygısının iş verimi ve iş üretkenliği üzerindeki etkilerinin incelenmesi: bilişim sektöründe bir araştırma. (Yayınlanmamış Yüksek Lisans Tezi). Maltepe Üniversitesi Sosyal Bilimler Enstitüsü, İstanbul.

Atılgan, Ö. (2019). İş yaşamında farklı kuşaklardaki iş güvencesizliği ve iş-aile çatışması algısı. İş ve Insan Dergisi, 6(1), 1-12.

Berglund, T., Furaker, B. \& Vulkan, P. (2014). Is job insecurity compensated for by employment and income security? Economic and Industrial Democracy, 35(1), 165-184.

Bustillo, R. \& Pedraza, P. (2010). Determinants of job insecurity in five european countries. European Journal of Industrial Relations, 16(1), 5-20.

Büssing, A. (1999). Can control at work and social support moderate psychological consequences of job insecurity? Results from a quasi-experimental study in the steel industry. European Journal of Work and Organizational Psychology, 8(2), 219-242.

Can, A. (2018). SPSS ile bilimsel araştırma sürecinde nicel veri analizi. Ankara: Pegem Akademi.

Clark, L. J. (2005). Moderators of the effects of perceived job insecurity: a comparison of temporary and permanent employees. (Unpubishled Doctoral Dissertation). Queensland University of Technology.

Çokluk, Ö. (2010). Lojistik regresyon analizi: kavram ve uygulama. Kuram ve Uygulamada Eğitim Bilimleri. 10(3), 1357-1407.

Darvishmotevali, M., Arasli, H. \& Kilic, H. (2017). Effect of job insecurity on frontline employee's performance: looking through the lens of psychological strains and leverages. International Journal of Contemporary Hospitality Management, 29(6), 1724-1744.

De Witte, H. (1999). Job insecurity and psychological well-being: review of the literature and exploration of some unresolved issues. European Journal of Work and Organizational Psychology, 8(2), 155-177.

Dede, E. (2017). İş güvencesizliği algısının ve örgütsel güven düzeyinin örgütsel vatandaşlık davranışı üzerindeki etkileri: devlet ortaokulu ve özel ortaokul öğretmenleri üzerine bir araştırma. (Yayınlanmamış Doktora Tezi). İstanbul Ticaret Üniversitesi Sosyal
Bilimler Enstitüsü, İstanbul.

Dereli, B. (2012). İş güvencesizliği kavramı ve banka çalışanlarının iş güvencesizliğine yönelik algılarının demografik özelliklerine göre incelenmesi. Ístanbul Ticaret Üniversitesi Sosyal Bilimler Dergisi, 11(21), 237-256.

Dığın, Ö. \& Ünsar, S. (2010). Çalışanların iş güvencesi algısının belirleyicileri ve iş güvencesinden memnuniyetin organizasyonel bağlilık, iş stresi ve işten ayrılma niyetine etkisi. Dumlupınar Üniversitesi Sosyal Bilimler Dergisi, 26, 133-145.

Dursun, S. \& Bayram, N. (2013). İş güvencesizliği algısının çalışanların kaygı düzeyleri üzerine etkisi: bir uygulama. "ISS, GÜÇ" Endüstri İlişkileri ve İnsan Kaynakları Dergisi, 15(3), 20-27.

Elman, C. \& O'Rand, A. (2002). Perceived job insecurity and entry into work-related education and training among adult workers. Social Science Research, 31, 49-76.

Ferrie, J., Shipley, M., Newman, K., Stansfeld, S. \& Marmot, M. (2005). Self-reported job insecurity and health in the whitehall ii study: potential explanations of the relationship. Social Science \& Medicine, 60, 1593-1602.

Green, F., Felstead, A. \& Burchell, B. (2000). Job insecurity and the difficulty of regaining employment: an empirical study of unemployment expectations. Oxford Bulletin of Economics and Statistics, 62, 855883.

Greenhalgh, L. \& Rosenblatt, Z. (2010). Evolution of research on job insecurity. International Studies of Management \& Organization, 40(1), 6-19.

Hellgren, J. \& Sverke, M. (2003). Does job insecurity lead to impaired well-being or vice versa? Estimation of cross-lagged effects using latent variable modelling. Journal of Organizational Behavior, 24, 215-236.

Hellgren, J., Sverke, M. \& Isaksson, K. (1999). A twodimensional approach to job insecurity: consequences for employee attitudes and well-being. European Journal of Work and Organizational Psychology, 8 (2), 179-195.

Karacaoğlu, K. (2015). Çalışanların iş güvencesizliğinin ișten ayrılma niyetleri üzerindeki etkisi: Alanya bölgesindeki beş yıldızlı otellerde bir araştırma. Uluslararası Alanya Isşletme Fakültesi Dergisi, 7(1), 13-21.

Karkoulian, S., Mukaddam, W., McCarthy, R. \& Messara, L. (2013). Job insecurity: a whirlpool of chronic powerlessness. Education, Business and Society: Contemporary Middle Eastern Issues, 6(1), 55-70. 
Kinnunen, U. \& Natti, J. (1994). Job insecurity in Finland: antecedents and consequences. European Work and Organizational Psychology, 4(3), 297-321.

Kinnunen, U., Mauno, S., Natti, J. \& Happonen, M. (1999). Perceived job insecurity: a longitudinal study among Finnish employees, European Journal of Work and Organizational Psychology, 8(2), 243-260.

Kinnunen, U., Makikangas, A., Mauno, S., De Cuyper, N. $\&$ De Witte, H. (2014). Development of perceived job insecurity across two years: associations with antecedents and employee outcomes. Journal of Occupational Health Psychology, 19(2), 243-258.

Kinnunen, U., Mauno, S., Natti, J. \& Happonen, M. (2000). Organizational antecedents and outcomes of job insecurity: a longitudinal study in three organizations in Finland. Journal of Organizational Behavior, 21, 443-459.

Kline, R. (2016). Principles and Practice of Structural Equation Modeling. NY: The Guilford Press.

Kovach, K. (1995). Employee motivation: addressing a crucial factor in your organization's performance. Employment Relations Today, 95, 93-107.

Lewchuk, W., Wolff, A., King, A. \& Polanyi, M. (2003). From job strain to employment strain: health effects of precarious employment. Just Labour, 3, 23-35.

Lim, V. (1996). Job insecurity and its outcomes: moderating effects of work-based and non-work based social support. Human Relations, 49(2), 171194.

Man, F. (2014). Üretim teknolojilerinin bilgisayarlaştırılması ve sonuçları. İçinde V. C. Özgüler (Ed.). Yeni teknolojiler ve çalışma hayatı (ss. 40-67). Eskişehir: Anadolu Üniversitesi Yayınları.

Nart, S. (2015). Tükenmişliğe etki eden faktörler ve tükenmişliğin yaratıcılık üzerine etkisi: televizyon programları yapımcıliğl sektörüne yönelik bir araştırma. (Yayınlanmamış Doktora Tezi). Balıkesir Üniversitesi Sosyal Bilimler Enstitüsü, Balıkesir.

Naswall, K. \& De Witte, H. (2003). Who feels insecure in Europe? Predicting job insecurity from background variables. Economic and Industrial Democracy, 24 (2), 189-215

Naswall, K., De Witte, H., Chirumbolo, A., Goslinga, S., Hellgren, J. \& Sverke, M. (2002). Who feels job insecurity? What characterizes insecure workers in Europe? İçinde M. Sverke vd. (Eds). European Unions in the Wake of Flexible Production. (ss. 6786). The National Institute for Working Life Report, Report No: 6.

Naswall, K., Sverke, M. \& Hellgren, J. (2005). The moderating role of personality characteristics on the relationship between job insecurity and strain, Work
\& Stress, 19(1), 37-49.

Otluoğlu, K. (2014). Algılanan iş güvencesizliğinin örgütler arası hareketlilik tercihine etkisi: algılanan istihdam edilebilirliğin biçimlendirici değişken rolü. ODTÜ Gelişme Dergisi, 41, 25-41.

Pfeffer, J. (1995). Rekabette üstünlüğün strrı: insan. (Çev. S. Gül). İstanbul: Sabah Kitapçılık.

Parker, S., Griffin, M., Sprigg, C. \& Wall, T. (2002). Effect of temporary contracts on perceived work characteristics and job strain: a longitudinal study. Personnel Psychology, 55, 689-719.

Peng, C. \& So, T. (2002). Logistic regression analysis and reporting: a primer, Understanding Statistics, 1(1), 31-70.

Polat, E. (2019a). İs güvencesizliği algısı ile iş üretkenliği ilişkileri: mevsimlik ve mevsimlik olmayan konaklama ișletmelerinde karşılaştırmalı bir araștırma. (Yayınlanmamış Doktora Tezi). Balıkesir Üniversitesi Sosyal Bilimler Enstitüsü, Balıkesir.

Polat, E. (2019b). Demografik değişkenlerin lider-üye etkileşimi üzerindeki etkisinin lojistik regresyon analizi ile belirlenmesi: konaklama işletmelerinde bir araştırma. Selçuk Üniversitesi Sosyal Bilimler Meslek Yüksekokulu Dergisi, 22(2), 742-757.

Poyraz, K. \& Kama, B. (2008). Algılanan iş güvencesinin, iş tatmini, örgütsel bağlılık ve işten ayrılma niyeti üzerindeki etkilerinin incelenmesi. Süleyman Demirel Üniversitesi İktisadi ve İdari Bilimler Fakültesi Dergisi, 13(2), 143-164.

Probst, T. (1998). Antecedents and consequences of job security: an integrated model. (Unpubished Doctoral Dissertation), University of Illinois at UrbanaChampaign.

Probst, T., Stewart, S., Gruys, M. \& Tierney, B. (2007). Productivity, counterproductivity and creativity: the ups and downs of job insecurity. Journal of Occupational and Organizational Psychology, 80, 479-497.

Rosenblatt, Z., Talmud, I. \& Ruvivo, A. (1999). A gender-based framework of the experience of job insecurity and its effects on work attitudes, European. Journal of Work and Organizational Psychology, 8(2), 197-217.

Schermelleh-Engel, K., Moosbrugger, H. \& Müller, H. (2003). Evaluating the fit of structural equation models: tests of significance and descriptive goodness-of-fit measures. Methods of Psychological Research Online, 8(2), 23-74.

Seçer, B. (2007). Kariyer sermayesi ve istihdam edilebilirliğin iş güvencesizliği üzerindeki etkisi. (Yayınlanmamış Doktora Tezi). Dokuz Eylül Üniversitesi, Sosyal Bilimler Enstitüsü, İzmir. 
Sekaran, U. (2003). Research methods for business. (Fourth Edition). NY: John Wiley \& Sons, Inc.

Selvi, Ü. \& Sümer, N. (2018). İş güvencesizliğinin etkileri: temel yaklaşımlar ve olumsuz etkileri düzenleyici faktörler üzerine bir derleme. Işs ve Insan Dergisi, 5(1), 1-17.

Sennett, R. (2017). Karakter aşınması. (Çev. B. Yıldırım). İstanbul: Ayrıntı Yayınları.

Sosyal Güvenlik Kurumu. (2020). SGK istatistik yıllıkları.

http://www.sgk.gov.tr/wps/portal/sgk/tr/kurumsal/ista tistik/sgk_istatistik_yilliklari, Erişim Tarihi: 22.03.2020.

Sop, S. A. (2019). Müşteri memnuniyetinin öncülleri ve ardılları: otel işletmeleri üzerine bir model analizi. Anatolia: Turizm Araştırmaları Dergisi, 30(3), 210 220.

Standing, G. (2017). Prekarya, yeni tehlikeli sinıf. (Çev. E. Bulut) İstanbul: İletişim Yayınları.

Staufenbiel, T. ve König, C. (2010). A model for the effects of job insecurity on performance, turnover intention, and absenteeism. Journal of Occupational and Organizational Psychology, 83, 101-117.

Sümer, N., Solak, N. \& Harma, M. (2013). İşsiz yaşam: işsizliğin ve iş güvencesizliğinin birey ve aile üzerindeki etkileri. İstanbul: Koç Üniversitesi Yayınları.

Sverke, M., Hellgren, J. \& Naswall, K. (2006). Job insecurity: a literature review. National Institute for Working Life Report, Report No 1: 2006.

Şeker, S. (2011). Çalışanlarda iş güvencesizliği ve tükenmislik ilişkisi: tıbbi tanttım sorumlularına yönelik bir alan araştırması. (Yayınlanmamış Yüksek Lisans Tezi). Dokuz Eylül Üniversitesi Sosyal Bilimler Enstitüsü, İzmir.

Şenol, F. (2010). Motivasyon araçlarının algılanmasında iş güvencesinin etkisi: otel işletmelerinde bir araştırma. (Yayınlanmamış Doktora Tezi). Afyon Kocatepe Üniversitesi, Sosyal Bilimler Enstitüsü, Afyon.

Yıldırım, B. \& Yirik, Ş. (2014). İşgörenlerin iş güvencesi algıları ve işten ayrılma niyetleri ilişkisi: Belek bölgesi beş yıldızlı otel çalışanları örneği. Iğdır Üniversitesi Sosyal Bilimler Dergisi, 6, 37-53. 